\title{
Exercise as A Potential Therapeutic Target for Diabetic Cardiomyopathy: Insight into the Underlying Mechanisms
}

\author{
Dae Yun Seo ${ }^{1}$, Jeong Rim Ko ${ }^{1}$, Jung Eun Jang ${ }^{1}$, Tae Nyun Kim ${ }^{1}$, Jae Boum Youm ${ }^{1}$, Hyo-Bum \\ Kwak ${ }^{2}$, Jun Hyun Bae ${ }^{3}$, Amy Hyein Kim ${ }^{1}$, Kyung Soo Ko ${ }^{1}$, Byoung Doo Rhee ${ }^{1}$ and Jin Han ${ }^{1, *}$ \\ 1 National Research Laboratory for Mitochondrial Signaling, Department of Physiology, BK21 Plus Project \\ Team, College of Medicine, Cardiovascular and Metabolic Disease Center, Inje University, Busan, Republic \\ of Korea; sdy925@gmail.com (D.Y.S.); kjrsos0217@gmail.com (J.R.K.); venus724@hanmail.net (J.E.J); \\ kimtn031@gmail.com (T.N.K.); youmjb@inje.ac.kr (J.B.Y.); amyhikim@gmail.com (A.H.K.); \\ kskomd@paik.ac.kr (K.S.K.); bdrhee@hanmail.net; (B.D.R.); phyhanj@inje.ac.kr (J.H.) \\ ${ }^{2}$ Department of Kinesiology, Inha University, Incheon, Republic of Korea; kwakhb@inha.ac.kr (H.B.K.) \\ ${ }^{3}$ Institute of Sport Science, Seoul National University, Seoul, Republic of Korea; (B.J.H.); baexx068@snu.ac.kr \\ * Correspondence: phyhanj@inje.ac.kr; Tel.: +82-051-890-6727
}

Received: date; Accepted: date; Published: date

\begin{abstract}
Diabetes mellitus is associated with cardiovascular, ophthalmic, and renal comorbidities. Among these, diabetic cardiomyopathy (DCM) causes the most severe symptoms and is considered to be a major health problem worldwide. Exercise is widely known as an effective strategy for the prevention and treatment of many chronic diseases. Importantly, the onset of complications arising from diabetes can be delayed or even prevented by exercise. Regular exercise is reported to have positive effects on diabetes mellitus and the development of DCM. The protective effects of exercise include the prevention of cardiac apoptosis, fibrosis, oxidative stress, and microvascular diseases, as well as improvement in cardiac mitochondrial function, and calcium regulation. The present review summarizes the recent findings to describe the potential mechanisms by which exercise may prevent DCM and heart failure.
\end{abstract}

Keywords: diabetes; exercise; cardiomyopathy; heart failure

\section{Introduction}

The prevalence of type 2 diabetes (T2DM) is a primary concern worldwide, and its incidence is increasing at an alarming rate [1]. T2DM leads to the impairment of both health and quality of life, causing chronic heart disease, cardiovascular disease, microvascular complications, and neurological abnormalities [2,3]. Cardiovascular disease, which is the primary complication in patients with diabetes mellitus, progresses to heart failure in more than $70 \%$ of cases, thereby drastically increasing the mortality and morbidity rate [4]. In addition, T2DM is associated with severe arteriosclerosis, hypertension, hyperlipidemia, and inflammation, all of which further contribute to the development of cardiovascular disease [5].

Recent molecular studies have suggested that the development of diabetic cardiomyopathy (DCM) involves mitochondrial dysfunction, fibrosis, oxidative stress, $\mathrm{Ca}^{2+}$ dysregulation, and microvascular dysfunction [6-8]. Numerous studies have shown that exercise can prevent cardiac injury and improve mitochondrial biogenesis in DCM [9-11]. Despite its broad clinical and preclinical impact, the mechanism underlying the protective effects of exercise on T2DM and DCM remains poorly understood.

Regualr exercise has undisputed benefits for diabetes. It helps to improve glucose and insulin metabolism and effectively decreases the risk factors for cardiovascular diseases. Increased physical 
activity and regular exercise improve cardiopulmonary fitness and reduce mortality and the development of DCM in type 2 diabetes [12]. Scientific literature suggests that the frequency as well as intensity of exercise is important to mitigate the causes of DCM. This review summarizes the mechanisms underlying the pathogenesis of DCM and the role of exercise as a potential therapeutic approach for clinical management of DCM.

\section{Clinical Aspects of DCM}

\subsection{Definition and characteristics of DCM}

Diabteses induced DCM is defined as a structural or functional myocardial dysfunction in the absence of coronary artery disease, hypertension, or valvular heart disease [13]. DCM is characterized by cardiac fibrosis, dysregulation of cardiac metabolism, and structural and functional changes of the left ventricle. These changes include left ventricular diastolic dysfunction, reduced left ventricular ejection fraction, pathological left ventricle hypertrophy, and interstitial fibrosis [14-16]. Collectively, these malfunctions increase the susceptibility of the heart to ischemic injury and the overall likelihood of developing heart failure. Left ventricular dysfunction with the stiffness of the ventricular wall is still common in patients with well-controlled type 2 diabetes [17]. Additionally, DCM progression leads to reduced myocardial contractility and relaxation, ultimately leading to heart failure with reduced ejection fraction (HFrEF) [18]. The mecahnisms underlying of DCM are summarised Figure 1 (adapted from [19]).

\section{Diabetes}

\section{FFA, Hyperglycaemia, Insulin resistance, and Lipotoxicity}

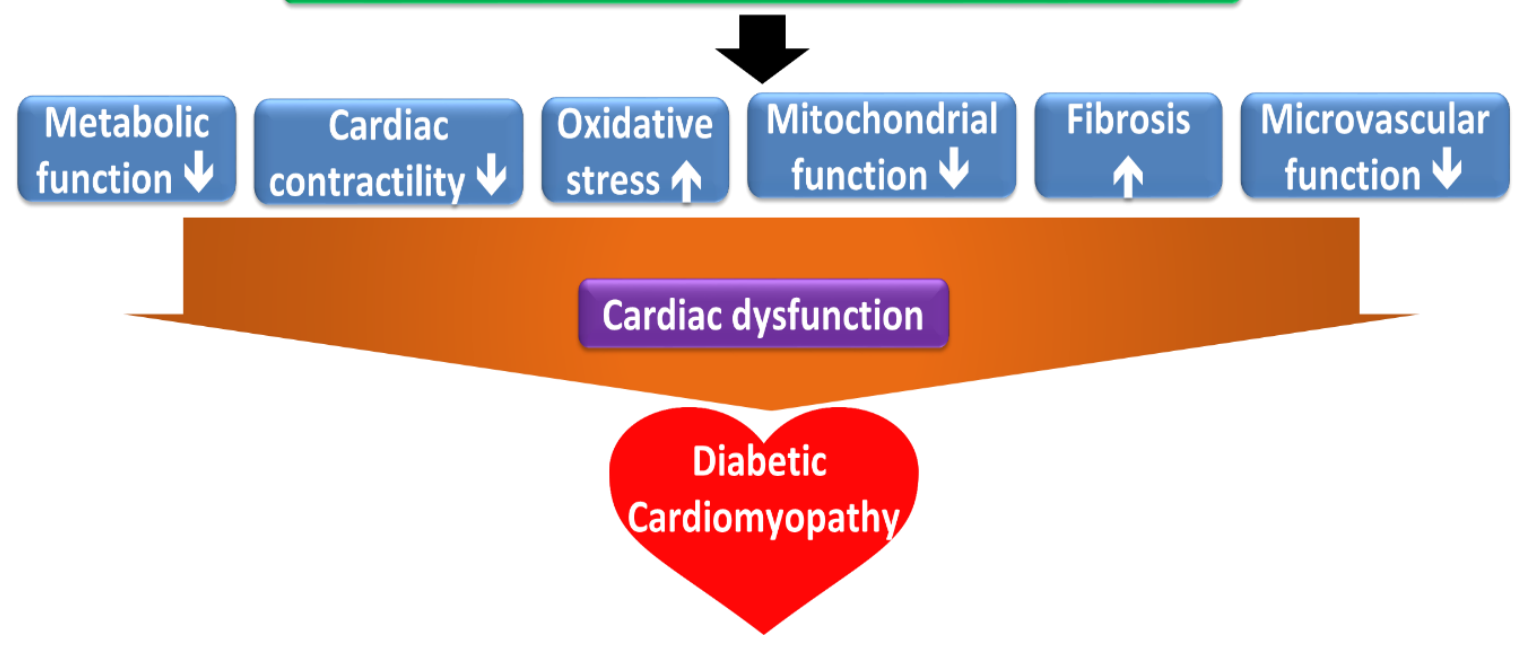

Figure 1. The multiple pathophysiological mechanisms of DCM. FFA, free fatty acid.

\subsection{Treatment strategies for $D C M$}

Myocardial functional abnormalities associated with diabetes reportedly depend on hyperglycemia and dysregulated energy metabolism. Despite the well-known effects of drugs and other interventions on controlling diabetes and associated complications, the strategy for comprehensive clinical management of DCM remains mostly unexplored. Therefore, therapeutic interventions for treating DCM have focused on controlling glucose and lipid levels, lowering blood pressure, and reducing coronary artery disease risk factors [20-22]. In recent years, pharmacological treatments of diabetes with beta-blockers ( $\beta$-blockers), calcium $\left(\mathrm{Ca}^{2+}\right)$ channel antagonists, and reninangiotensin-aldosterone system inhibitors have shown to impede coronary artery disease in T2DM $[23,24]$. Furthermore, metformin and sodium-dependent glucose transporter 2 (SGLT2) inhibitors are shown to be effective in treating DCM $[25,26]$. Recently, several studies have reported that nonpharmacological interventions, such as increasing physical activity and regular exercise improve 
health and quality of life in patients with obesity or T2DM and its associated complications [27,28]. Regular exercise is known to improve cardiac function and exert protective effects against cardiovascular disease and ischemic damage [29]. It also induces physiological cardiac hypertrophy through cardiac cell growth and improves cardiac metabolism and function [30]. Further, regular exercise inhibits cardiomyocytes apoptosis and myocardial fibrosis and improves hemodynamic impairment caused by T2DM associated hyperglycemia [31]. Another study has reported that exercise improves systemic glucose regulation and insulin sensitivity and decreases cardiac fibrosis and oxidative stress, thereby reducing the risk factors for cardiovascular disease [32]. Collectively, these studies indicate that exercise plays an essential role in the regulation of cardiac function and may have the potential for therapeutic management of DCM.

\subsection{Clinical significance of exercise for the treatment of DCM}

The majority of published studies have reported that moderate to high-intensity exercise can increase the survival rate in patients with T2DM [33-35]. Hu et al. [36] reported that moderate to highintensity exercise reduces the risk factors for cardiovascular diseases by lowering the body mass index (BMI) and blood pressure. Exercise duration was reported as an important factor in achieving the health benefits that minimize the risk factors for cardiovascular diseases. Karjalainen et al. [37] found that habitual and leisure-time physical activities decreased the risk factors for cardiovascular disease. However, home-based exercises did not significantly ameliorate cardiovascular disease risk factors [38,39]. According to the 2019 American Diabetes Association (ADA) guidelines, 150 minutes or more of moderate-to-vigorous intensity aerobic activity per week is recommended to harness the protective effects of exercise against diabetic complications [40]. Over the long-term, regular exercise of moderate-to-vigorous intensity is an effective strategy to prevent the development of DCM. However, it is difficult for diabetic patients to exercise on a long-term basis. Table 1 presents a summary of clinical studies on the preventive effects of exercise on diabetes-related cardiovascular diseases.

\section{Potential mechanisms of protective effects of exercise against DCM}

\subsection{Cardiac cell metabolism}

Impaired energy metabolism in the myocardium or "metabolic remodeling of the heart" can lead to structural changes in cardiomyocytes, eventually leading to cardiomyopathy [14]. Under normal physiological conditions, glucose transporter-4 (GLUT-4), an intracellular protein, is translocated to the cell membrane in response to insulin and facilitates glucose uptake and utilization [41,42]. In addition, in diabetes, expression and function of GLUT-4 are compromised, leading to a marked reduction in glucose transport and impaired energy utilization in the myocardium [43]. However, many studies have reported that moderate exercise can reverse these effects by increasing GLUT-4 expression and glucose transport, and activating the pyruvate dehydrogenase complex [44]. Related findings suggest that exercise protects pancreatic beta cells by inducing the expression of insulin-sensitive adenosine monophosphate-activated protein kinase (AMPK) and prevents energy metabolism dysfunction in insulin-deficient diabetes mellitus [45]. Furthermore, exercise has been shown to reduce Forkhead box protein O1 (FOXO1) and FOXO1-related factors in pancreatic beta cells and the myocardium of obese rats and activate insulin signaling pathways [46]. Exercise enhances the function of insulin-regulated glucose transporters via upregulating the expression of protein kinase $C$ [47]. Therefore, exercise exerts its protective effects by inducing the pancreatic beta cells to increase insulin secretion, activating the insulin signaling pathway, upregulation of GLUT-4 expression, and enhancing intracellular energy metabolism. 
2 Table 1: A summary of clinical studies on the preventive effects of exercise in diabetes-related cardiovascular diseases.

\begin{tabular}{|c|c|c|c|c|c|c|c|}
\hline \multirow{2}{*}{$\begin{array}{c}\text { Study Type } \\
\text { (Design) }\end{array}$} & \multirow{2}{*}{ Subjects } & \multicolumn{4}{|c|}{ Exercise Intervention } & \multirow{2}{*}{ Effects } & \multirow{2}{*}{ Ref } \\
\hline & & Type & Frequency & Time (min) & Duration & & \\
\hline $\begin{array}{l}\text { Human } \\
\text { (RCT) }\end{array}$ & $\begin{array}{l}\text { Patients with } \\
\text { T2DM }\end{array}$ & Aerobic \& Resistance Exercise & 3-5 days/wk & $75 \mathrm{~min} / \mathrm{session}$ & 12 wks & $\begin{array}{l}\uparrow \text { Anti-atherosclerotic effects } \\
\downarrow \text { Cardiovascular events } \\
\uparrow \text { Flow-mediated endothelium- } \\
\text { dependent vasodilation }\end{array}$ & [80] \\
\hline $\begin{array}{l}\text { Human } \\
\text { (non-RCT) }\end{array}$ & $\begin{array}{l}\text { Patients with } \\
\text { T2DM }\end{array}$ & Aerobic Exercise & 4 days/wk & 4-7 hours/day & 24 wks & $\begin{array}{l}\downarrow \text { Hepatic triglyceride } \\
\downarrow \text { Paracardial fat volume }\end{array}$ & [48] \\
\hline $\begin{array}{c}\text { Human } \\
(\mathrm{RCT})\end{array}$ & $\begin{array}{l}\text { Patients with } \\
\text { T2DM }\end{array}$ & $\begin{array}{l}\text { High intensity interval } \\
\text { training }\end{array}$ & NA & NA & 12 wks & $\begin{array}{l}\uparrow \text { Left ventricular mass (g) } \\
\uparrow \text { Early diastolic filling rate change } \\
\text { (ml/s) } \\
\uparrow \text { Peak torsion change } \\
\downarrow \text { Body weight }(\mathrm{kg}) \\
\downarrow \text { Liver fat }(\%) \\
\downarrow \text { ALP }(\mathrm{U} / \mathrm{I}) \\
\downarrow \text { HbA1c }(\%) \\
\downarrow 2 \mathrm{hrs} \mathrm{glucose}(\mathrm{pmol} / \mathrm{l}) \\
\downarrow 2 \mathrm{hrs} \text { AUGC }(\mathrm{mmol} / \mathrm{l})\end{array}$ & [49] \\
\hline
\end{tabular}


5 Table 2: A summary of pre-clinical studies on the preventive effects of exercise in diabetes-related cardiovascular diseases.

\begin{tabular}{|c|c|c|c|c|c|c|}
\hline \multirow{2}{*}{ Subjects } & \multicolumn{4}{|c|}{ Exercise Intervention } & \multirow{2}{*}{ Effects } & \multirow{2}{*}{ Ref } \\
\hline & Type & Frequency & Time (min) & Duration & & \\
\hline $\begin{array}{c}\text { 7-wk old male } \\
\text { C57BL/6 }\end{array}$ & Aerobic Exercise & 5 days/wk & $60 \mathrm{~min} /$ day & 15 wks & $\begin{array}{l}\uparrow \text { Ejection fractions (\%) } \\
\uparrow \text { Factional shortening (\%) } \\
\downarrow \text { Body weight (g) } \\
\downarrow \text { Heart weight (mg) } \\
\uparrow \text { Ratio of Bax/Bcl-2 } \\
\downarrow \text { mRNA of Collagen I \& III } \\
\uparrow \text { SSBP1, TWINKLE, TOP1MT, mRNA level of ND6 \& CYTB } \\
\uparrow \text { PGC-1 } \alpha \text {, NRF1, TFAM, TFB2M } \\
\uparrow p-A k t\end{array}$ & [10] \\
\hline $\begin{array}{l}\text { Obese diabetic } \\
\text { mice }(\mathrm{db} / \mathrm{db})\end{array}$ & Aerobic Exercise & 5 days/wk & $\begin{array}{l}330 \mathrm{~m} \text { run at speed } \\
\text { of } 10 \mathrm{~m} / \mathrm{min}(2 \\
\mathrm{wks})+330 \mathrm{~m} \text { run } \\
\text { at speed of } 11 \\
\mathrm{~m} / \mathrm{min}(3 \mathrm{wks})\end{array}$ & $5 \mathrm{wks}$ & $\begin{array}{l}\uparrow \text { Body weight (gm) } \\
\uparrow \text { Mean blood pressure (mmHg) } \\
\uparrow \text { Heart weight (gm) } \\
\uparrow \text { Blood glucose (mg/dL) } \\
\uparrow \text { Stroke volume }(\mu \mathrm{L}) \\
\uparrow \text { Ejection fraction (\%) } \\
\uparrow \text { Fractional Shortening (\%) }\end{array}$ & [50] \\
\hline $\begin{array}{l}\text { STZ-diabetic rats } \\
\text { (single injection } \\
\text { of STZ: } 55 \\
\mathrm{mg} / \mathrm{kg} \text { ) }\end{array}$ & Aerobic Exercise & 5 days/wk & $\begin{array}{l}10-15 \mathrm{~min} / \text { day, } \\
\text { total } 60 \mathrm{~min} \\
\text { (speed } 2 \mathrm{~m} / \mathrm{min} \text { at } \\
\text { grade } 5 \% \text { ) }\end{array}$ & 7 wks & $\begin{array}{l}\uparrow \text { Citrate synthase activity }(\mu \mathrm{mol} / \mathrm{tissue}(\mathrm{g}) / \mathrm{min}) \\
\uparrow \text { Heart Rate }(\mathrm{bpm}) \\
\downarrow \text { Left ventricular end diastolic diameter \& Left ventricular end } \\
\text { systolic diameter (mm) } \\
\uparrow \text { Fractional shortening (\%) }\end{array}$ & [51] \\
\hline
\end{tabular}




\begin{tabular}{|c|c|c|c|c|c|c|}
\hline & & & & & $\begin{array}{l}\uparrow \text { Ejection fraction (\%) } \\
\uparrow \text { Cardiac output (ml/min) } \\
\downarrow \text { QRS interval (m/sec) } \\
\uparrow \text { Myocyte contractile kinetics velocity }(\mu \mathrm{m} / \mathrm{sec}) \text {, extent of cell } \\
\text { shortening }(\mu \mathrm{m}) \text {, and relengthening velocity }(\mu \mathrm{m} / \mathrm{sec}) \\
\downarrow \text { Myocyte contractile kinetics time to } 50 \% \text { peak contractile velocity } \\
\quad(\mathrm{m} / \mathrm{sec}) \& \text { time to } 50 \% \text { peak relaxation velocity }(\mathrm{m} / \mathrm{sec})\end{array}$ & \\
\hline $\begin{array}{c}7 \text { wk old diabetic } \\
\text { rats (Injection } \\
\text { STZ } 65 \mathrm{mg} \text { ) }\end{array}$ & Aerobic Exercise & 5 days/wk & $\begin{array}{c}60 \mathrm{~min} / \text { day }(20 \\
\mathrm{m} / \mathrm{min} \text { pace })\end{array}$ & 9 wks & $\begin{array}{l}\uparrow \text { Cytoplasmic area (\% of intracellular area) } \\
\uparrow \text { Lipid droplets }\left(\mu \mathrm{m}^{2}\right) \\
\uparrow \text { Mitochondria area, myofibrillar area, mitochondria quality } \\
\text { index, cytoplasm area, and collagen fiber circumference }\end{array}$ & {$[52]$} \\
\hline $\begin{array}{c}\text { Female Wistar } \\
\text { Rats }\end{array}$ & $\begin{array}{c}\text { Aerobic Exercise } \\
\text { \& Resistance } \\
\text { Exercise }\end{array}$ & 5 days/wk & $\begin{array}{l}\text { Aerobic: } 1 \mathrm{hr} / \text { day } \\
\quad(40-60 \% \text { of } \\
\text { maximal running } \\
\text { speed }) \\
\text { Resistance: } \\
\text { moderate } \\
\text { intensity ( } 40-60 \% \\
\text { of maximal load } \\
\text { via body weight) }\end{array}$ & 8 wks & $\begin{array}{l}\downarrow \text { Oxidative stress } \\
\downarrow \text { Body weight (g) } \\
\uparrow \text { Glycaemia (mg/dL) } \\
\downarrow \text { Maximal running test (s) } \\
\uparrow \text { Maximal load test (\% of body weight) } \\
\uparrow \text { Left ventricle mass (g), left ventricle cavity in diastole (cm), and } \\
\quad \text { relative wall thickness } \\
\uparrow \text { Only aerobic exercise: Systolic function (\%) and diastolic } \\
\text { function }(\mathrm{m} / \mathrm{s})\end{array}$ & [53] \\
\hline $\begin{array}{l}3 \text { month old } \\
\text { male Sprague } \\
\text { Dwaley rat } \\
\text { (Single dose of }\end{array}$ & $\begin{array}{l}\text { High intensity of } \\
\text { Aerobic Exercise }\end{array}$ & 5 days/wk & NA & $4 \mathrm{wks}$ & $\begin{array}{l}\downarrow \text { Body weight }(\mathrm{g}) \\
\uparrow \text { Plasma glucose }(\mathrm{mg} / \mathrm{dL}) \\
\uparrow \text { NOX2 \& NOX4, p67phox } \\
\downarrow \text { SERCA2 } \\
\downarrow \text { eNOS \& BH4 }\end{array}$ & [54] \\
\hline
\end{tabular}




\begin{tabular}{|c|c|c|c|c|c|c|}
\hline $\begin{array}{c}\text { alloxan; } \\
200 \mathrm{mg} / \mathrm{kg})\end{array}$ & & & & & & \\
\hline $\begin{array}{l}\text { BBDR } \\
\text { (Biomedical } \\
\text { Research } \\
\text { Models) male } \\
\text { rats }\end{array}$ & Aerobic Exercise & 5 days/wk & $50 \mathrm{~min} /$ day & 8 wks & $\begin{array}{l}\uparrow \text { Plasma glucose (mg/dl) \& } \mathrm{HbA} 1 \mathrm{c}(\%) \\
\uparrow \mathrm{LV} \text { end-systolic volume }(\mu \mathrm{l}), \mathrm{LV} \text { end-diastolic volume }(\mu \mathrm{l}) \text {, } \\
\text { and } \mathrm{LV}-\mathrm{dp} / \mathrm{dt}(\mathrm{mmHg} / \mathrm{s}) \\
\uparrow \text { Myocardial mitochondria fractional area (\%) }\end{array}$ & [47] \\
\hline $\begin{array}{l}\text { Adult Sprague- } \\
\text { Dawley male rats } \\
+ \text { doxorubicin } \\
\text { (DOX: } 20 \mathrm{mg} / \mathrm{kg} \\
\text { body weight) }\end{array}$ & Aerobic Exercise & 5 days/wk & $\begin{array}{l}60 \mathrm{~min} / \text { day } \\
(30 \mathrm{~m} / \mathrm{min})\end{array}$ & NA & $\begin{array}{l}\uparrow \text { Protect against Dox-mediated damage in mitochondria } \\
\downarrow \text { Caspase } 3 \text { \& calpain } \\
\uparrow \text { SOD1, SOD2, Catalase, GPX1, catalase, and HSP72 } \\
\downarrow \text { Hydrogen peroxide (pmol/mg/min) }\end{array}$ & [55] \\
\hline $\begin{array}{l}8 \text { wks old female } \\
\text { C57BL6 mice }\end{array}$ & $\begin{array}{c}\text { Aerobic Exercise } \\
+ \text { Resveratrol } \\
\text { supplementation }\end{array}$ & 5 days/wk & $30 \mathrm{~min} /$ day & 8 wks & $\begin{array}{l}\uparrow \text { Left ventricle posterial wall (mm) } \\
\uparrow \text { Intraventricular septum (mm) } \\
\uparrow \text { Left ventricle internal dimension (mm) } \\
\uparrow \text { Fractional shortening } \\
\downarrow \text { Citrate synthase activity (mmol/mg/min) } \\
\downarrow \text { ANF \& UCP3 }\end{array}$ & {$[56]$} \\
\hline $\begin{array}{l}\text { Sprague-dawley } \\
\text { (SD) diabetic rats }\end{array}$ & Aerobic Exercise & 5 days/wk & $\begin{array}{l}60 \mathrm{~min} / \text { day } \\
\text { Low intensity: } \\
20 \mathrm{~m} / \mathrm{min} \\
\text { High intensity: } \\
34 \mathrm{~m} / \mathrm{min} \\
\end{array}$ & 12 wks & $\begin{array}{l}\downarrow \text { Left ventricular \& diastolic volume } \\
\downarrow \text { caspase } 3, \text { cTn- } 1(\mathrm{lg} / \mathrm{l}), \mathrm{Grp} 78, \mathrm{CHOP} \text {, and Caspase } 12\end{array}$ & [9] \\
\hline $\begin{array}{l}\text { Sprague-Dawley } \\
\text { rats (intravenous }\end{array}$ & Aerobic Exercise & 5 days/wk & $\begin{array}{l}60 \mathrm{~min} / \text { day } \\
(32 \mathrm{~m} / \mathrm{min})\end{array}$ & 10 wks & $\begin{array}{l}\downarrow \text { Body weight }(\mathrm{g}) \\
\downarrow \text { Glucose }(\mathrm{mmol} / \mathrm{L})\end{array}$ & [29] \\
\hline
\end{tabular}

.




\begin{tabular}{c|l|l|l|l|l|}
\hline $\begin{array}{c}\text { injection of } \\
\text { streptozotocin: } \\
60 \mathrm{mg} / \mathrm{kg}\end{array}$ & & & & $\begin{array}{l}\downarrow \text { Triglycerides (mmol/L) } \\
\uparrow \text { Glucose oxidation (nmol/g/min) } \\
\uparrow \text { Glycolysis (nmol/g/min) } \\
\uparrow \text { Aortic flow (ml/min) }\end{array}$ \\
\hline $\begin{array}{c}6-8 \mathrm{wk} \text { male } \\
\text { wistar rat }+ \\
\text { Doxorubicin } \\
(20 \mathrm{mg} / \mathrm{kg})\end{array}$ & Aerobic Exercise & 5 days/wk & $60 \mathrm{~min} /$ day & $14 \mathrm{wks}$ & $\begin{array}{l}\uparrow \text { Mitochondrial respiration, calcium tolerance, oxidative damage, } \\
\text { and heat shock proteins } \\
\begin{array}{c}\text { State } 3 \text { respiration, respiratory control ratio, uncoupled } \\
\text { respiration, aconitase activity, and protein sulfhydryl content }\end{array}\end{array}$ \\
\hline
\end{tabular}

$\uparrow$, up; $\downarrow$, down; SSBP1; Single-stranded DNA-binding protein1; PGC-1 $\alpha$, Peroxisome proliferator-activated receptor gamma coactivator 1-alpha; NRF1, Nuclear Respiratory Factor 1; TFAM, Mitochondrial transcription factor A; TFB2M, Mitochondrial dimethyladenosine transferase 2; 8 NOX2, NADPH oxidase 2; NOX4, NADPH oxidase 4; SERCA2, sarco/endoplasmic reticulum Ca2+-ATPase; eNOS, Endothelial nitric oxide 9 synthase; $\mathrm{BH}_{4}$, Tetrahydrobiopterin; $\mathrm{HbA1c}$, Hemoglobin A1c; LV, left ventricle; SOD1, Superoxide dismutase 1; SOD2, Superoxide dismutase 10 2; GPX1, Glutathione peroxidase 1; HSP72, Heat shock protein 72; ANF, Atrial natriuretic peptide; UCP3, Uncoupling protein 3. 


\subsection{Calcium regulation in cardiac cells}

Calcium plays a pivotal role in muscle fiber differentiation, skeletal muscle contraction, cell signal transduction, and energy production [7]. Dysregulated $\mathrm{Ca}^{2+}$ homeostasis leading to myocardium contractile dysfunction is an important marker of DCM [58,59]. The reduced activity of the sarcoplasmic reticulum $\mathrm{Ca}^{2+}$-ATPase (SERCA2a) decreases the rate of $\mathrm{Ca}^{2+}$ transportation in the sarcoplasmic reticulum [58]. Patients with T2DM exhibit reduced $\mathrm{Na}^{+}-\mathrm{Ca}^{2+}$ exchange in the cardiomyocytes, whereas the SERCA2a retains its normal function $[51,58,60]$. This leads to the accumulation of $\mathrm{Ca}^{2+}$ ions in the sarcoplasmic reticulum. On the other hand, exercise improves the expression and activity of SERCA2a, and regulates $\mathrm{Ca}^{2+}$ levels via $\mathrm{Ca}^{2+}$ calmodulin-dependent protein kinase phosphorylation, thereby improving the myocardial contractile function [54]. Stølen et al. [49] noted that intermittent, high-intensity exercise-mediated increases in myocardial contractility could be mimicked by restoring L-type $\mathrm{Ca}^{2+}$ channels, increasing $\mathrm{T}$-transverse tubule density, and enhancing $\mathrm{Ca}^{2+}$ release and excitation-contraction coupling.

\subsection{Mitochondrial function of cardiac cells}

Mitochondria are central to energy metabolism, and heart mitochondria process the highest amount of oxygen to meet the energy requirments for the proper functioning of the organ. Therefore, mitochondrial dysfunction can play an important role in the pathogenesis of DCM [42]. The ultrastructural changes of the cardiac mitochondria associated with DCM include reduction of mitochondrial density, mitochondrial swelling, damage to the inner membrane, and increased mitochondrial matrix [17]. Moderate-intensity exercise has been shown to reduce these ultrastructural changes in diabetes and exerts a protective effect on the mitochondrial function [50]. Exercise regulates mitochondrial metabolism and activates downstream transcription factors such as PPAR gamma co-activator-1 alpha (PGC-1 $\alpha$ ) [61,62]. Moreover, exercise induces mitochondrial DNA replication, transcription, and mitochondrial biogenesis [63]. Exercise improves the contractility of cardiomyocytes by regulating calcium cycling and ameliorates mitochondrial $\mathrm{Ca}^{2+}$ uptake [52]. In particular, resistance exercise improves mitochondrial efficiency and heart function via increase in PGC-1 $\alpha$ and mitochondrial transcription factor A (TFAM) expression [10]. Furthermore, unlike moderate-intensity exercise, high-intensity exercise is reported to increase cardiac mitochondrial content. However, Veeranki et al. [50] found that moderate-intensity exercise prevents DCMassociated contractile dysfunction and restores mitochondrial function and connexin 43 levels in diabetic $(\mathrm{db} / \mathrm{db})$ mice models. These results suggest that exercise plays vital role in cardiac mitochondrial metabolism and maximizes calcium efficiency. Hence, the enhancement of mitochondrial biogenesis in the diabetic myocardium may correlate with exercise intensity and warrants further research in this field.

\subsection{Oxidative stress in cardiomyocytes}

T2DM associated hyperglycemia, chronic inflammation, and oxidative stress are linked with mitochondrial dysfunction and the development of DCM [64]. Hyperglycemia induces oxidative stress via enhancing the production of oxygen free radicals and facilitates cardiomyocyte apoptosis $[24,65]$. The excess oxygen free radicals interact with lipids, proteins, and DNA and lead to pathological changes [24]. However, studies have shown that exercise reduces the production of reactive oxygen species and alleviates oxidative stress-mediated damage [57]. Besides, exercise improves glucose metabolism in the diabetic myocardium and pancreas. Long-term regular exercise has been shown to decrease nicotinamide adenine dinucleotide phosphate (NADPH) oxidase, increase nitric oxide synthase and nitric oxide production, and enhance anti-oxidative activity in the endothelial cells [66]. The nuclear factor erythroid 2-related factor 2 (Nrf2) is important factor in defending cariomyocytes against intracellular oxidative stress and is a crucial regulator of antioxidant response elements [67-71]. Cardiomyocytes of Nrf2 knockout mice are reported to suffer from oxidative stress. Exercise upregulates the expression of Nrf2, thereby mitigating oxidative stress [69]. However, it has been reported that low-intensity exercise reduces malondialdehyde, an indicator of oxidative stress, and upregulates the expression and function of anti-oxidant enzymes 
such as superoxide dismutase, glutathione peroxidase, and catalase in the myocardium [53]. These studies demonstrate that exercise exerts anti-oxidative effects by regulating the activity of enzymes, oxygen-free radicals, and nuclear factors, and these effects depend on the intensity of exercise.

\subsection{Myocardial fibrosis}

T2DM-induced accumulation of extracellular matrix (ECM) proteins in the heart, also known as myocardial fibrosis, is the most marked histopathological change associated with DCM $[8,14,15,72-$ 76]. Myocardial fibrosis leads to structural and functional changes in the heart through collagen deposition, interstitial fibrosis, and perivascular fibrosis [14]. However, several studies have reported that exercise can reduce myocardial fibrosis and promote cardiac structure remodeling, eventually improving cardiac function in DCM [10]. Exercise is also reported to reduce myocardial fibrosis by lowering blood pressure [11]. Moreover, exercise has been shown to increase matrix metalloproteinase- 2 and collagen degradation and inhibit myocardial fibrosis in obese mice [72,77]. The interaction between collagen and glucose leads to the formation of advanced glycation end products, which induce endothelial dysfunction and arterial and cardiac cirrhosis [15]. Novoa et al. [54] reported that long-term, regular, high-intensity exercise exerts positive effects on cardiac structure remodeling by decreasing cardiomyocyte hypertrophy, collagen deposition, and myocardial fibrosis. Therefore, exercise-induced abrogation of myocardial fibrosis may be highly correlated with energy metabolism, ans decreased blood glucose and glycogen deposition in the heart.

\subsection{Apoptosis of cardiomyocytes}

T2DM-induced apoptosis of cardiomyocytes is one of the hallmark features of DCM. Hyperglycemia induces the activation of mitochondrial cytochrome $\mathrm{c}$ and promotes its release into the cytoplasm. It activates caspase-3 and the downstream apoptotic pathway in cardiomyocytes [8]. These changes are key factors leading to cardiac hypertrophy, cardiac remodeling, and heart failure in DCM $[17,78]$. The c-Jun N-terminal kinases (JNKs) group of mitogen-activated protein kinases (MAPKs) are activated under the conditions of metabolic disorders and T2DM [20,79-82]. The JNKs promote apoptosis in cardiomyocytes by activating the pro-apoptotic proteins caspase 8 and Bax [57]. Veeranki et al. [50] showed that exercise improves the mitochondrial transmembrane potential and inhibits cytochrome c leakage into the cytoplasm, thereby preventing the apoptosis of cardiomyocytes. Another study reported that exercise could reduce the phosphorylation of JNKs and inhibit the downstream apoptotic pathway in obese mice [83]. Additionally, exercise has shown to increase the expression of B cell leukemia/lymphoma 2 (BCL-2) in cardiomyocytes of diabetic animal models. This result suggest that exercise can inhibit cardiac apoptosis or prevent the development of cardiac abnormalities [10]. Kanter et al. [84] reported the therapeutic effects of low-intensity exercise against apoptotic, biochemical, and morphological changes in the cardiac tissues. Khakdan et al. [85] showed that high-intensity interval training increased the expression of Sirtuin 1 (Sirt1) and BCL-2, and improved the left ventricular ejection fraction (LVEF) and fractional shortening (FS) significantly. Furthermore, studies have revealed that exercise improves diabetes via inhibition of endoplasmic reticulum (ER) stress-induced apoptosis and the extent of such inhibition depends on the intensity of exercise [9].

\subsection{Microvascular function of cardiomyocytes}

Hyperglycemia induced microvascular changes are manifested as vascular endothelial defects and endothelial cell dysfunction, and they elicit a partial inflammatory response in the vascular endothelium [86]. These changes can affect glucose and insulin transport into cells, thereby inducing abnormal tissue function [18]. Exercise is shown to exert a protective effect on blood vessels and endothelial dysfunction [87], and enhance the ventricular diastolic function [88]. It also improves the microvascular responses to insulin and improves insulin signaling. Exercise helps to maintain the optimal blood vessel function and the balance between hypotensive nitric oxide and hypertensive endothelin-1 via the insulin receptor substrate-1/phosphatidylinositol-3-kinase/protein kinase B (IRS1/PI3K/AKT) and MAPK signaling pathways [81]. Details of exercise-mediated pre-clinical studies 
and the potential mechanisms of the protective role of exerciseon DCM are presented in Figure 1 and Table 2 .

\section{Prospective new biomarkers in DCM}

The pathophysiologic mechanisms of DCM are multifactorial processes that include altered cardiac cell metabolism, impaired calcium regulation, mitochondrial dysfunction, increased oxidative stress, altered myocardial fibrosis, higher induction of apoptosis, and microvascular disease. Exercise can protect the myocardium by altering these mechanisms for the better. However, the problem is that no known biomarkers are able to discriminate patients with DCM, although there are several biomarkers such as natriuretic peptides that may be helpful in the diagnosis of heart failure. Cardiac injury markers including C-reactive protein and troponins are released in relation to different diseases such as myocardial infarction, myocarditis, or any secondary cardiac injury. These markers have not provided valuable information for early detection of DCM in the clinical setting. Thus, new biomarkers must be identified for early detection of cardiac responses such as hypertrophy, contractibility, steatosis, or even fibrosis [89].

Cardiotrophin-1 (CT-1), a member of interleukin-6 family, was originally isolated for its ability to induce a hypertrophic response in neonatal cardiac myocytes [90]. CT-1 is mostly released from cardiomyocytes after oxidative and mechanical stress or renin-angiotensin-aldosterone sytem stimulation [91]. CT-1 is known to modulate cardiac hypertrophy, contractility, fibrosis and ischemia through reduction of cell proliferation, apoptosis, oxidative stress and inflammation, and by activation of JAK/STAT and MAPK pathways [91,92]. A very interesting field of study is the physiological and reversible cardiac hypertrophy adaptive response to exercise. In one study, CT-1 levels were examined in a small and select cohort of elite athletes. Although there were no differences between basal circulating CT-1 levels in well trained athletes and controls, CT-1 levels during exercise were significantly different in the trained athlete group compared to the control group [93].

In regards to prospective new biomarkers related to the contractile function of the heart in DCM, Activin A, a molecule secreted by epicardial adipose tissue, may induce contractile dysfunction and insulin resistance in cardiomyocytes [94]. Circulating Activin A levels were negatively associated with glucose metabolism in cardiomyocytes, and positively with left ventricular mass/volume-ratio, reflecting a potential harmful effect on early diabetic cardiomyopathy in patients with T2DM [95]. Long-term regular exercise is associated with reduced risk for the development of metabolic and cardiovascular diseases. Although plasma Activin A levels increased after single exercise session (45 minutes) [96], there is very limited information about the circulating profile of this molecule with long-term exercise and its role in the mechanisms of DCM.

Normal fat accumulation in the myocardium may be a protective response to provide a store of fuel for subsequent oxidation, whereas in DCM, a chronic imbalance between lipid storage and lipid oxidation may lead to cardiac dysfunction [97]. Steatosis-related factors released from the heart may be useful for early DCM detection. Heart-type fatty acid binding protein (H-FABP) is a cardiac cytosolic protein that transports fatty acids to the mitochondria, and is up-regulated and located at the sarcolemma after lipid delivery [98]. H-FABP might be released into the blood after myocardial injury even though it is undetectable in healthy subjects. The presence of H-FABP has been observed in patients with T2DM in the early stages of cardiac injury. [99]. On the other hand, H-FABP has been used as an indicator of fatty acid utilization in the heart. Compared to the control group, rabbits with myocardial infarction (MI) group had down-regulated cardiac expression of H-FABP. Exercise training increased H-FABP expression in the MI group, whereas it had no effect on H-FABP expression in the control group [100]. These results indicate that MI decreased cardiac fatty acid utilization, and that exercise could improve it. Most previous articles have discussed the diagnostic or prognostic role of H-FABP in a specific clinical diagonis such as acute coronary syndrome or acute pulmonary embolism [101]. Future studies should address the potential role of circulating $\mathrm{H}$ FABP levels as an indicator of early DCM and whether the H-FABP biomarker is suitable to evaluate the beneficial effects of exercise training in patients with DCM.

Likewise, chronic hyperglycemia facilitates the reaction of glucose with collagen to form advanced glycation end-products that promote the crosslinking of collagen molecules to produce 
fibrosis [102]. Fibrotic components may be an important link to the pathologic mechanism of DCM. Insulin-like growth factor binding protein-7 (IGFBP-7), which modulates insulin receptor activity by interaction with insulin growth factor-1, has been evidenced as a serum biomarker for diastolic dysfunction associated with vascular remodeling and cardiac hypertrophy and fibrosis in metabolic syndrome [103]. In addition, IGFBP-7 is associated with the severity of diastolic dysfunction [104]. Moreover, IGFBP-7 has been involved in fibrogenesis in patients with diabetes [105]. IGFBP-7 levels increase in diabetes patients with normal diastolic function, and in patients with diastolic dysfunction either with or without diabetes; the highest values of IGFBP-7 levels are found in patients with diastolic dysfunction and diabetes [106].

Recently, cardiac microRNAs have been discovered as key modulators in the pathogenesis of DCM [107]. Circulating microRNAs present in the blood are extremely stable and may be potentially used as diagnostic and prognostic biomarkers for diabetic macrovascular complications as well as DCM [108]. Indeed, a number of microRNAs in plasma or whole blood have been reported in diabetic individuals. The microRNA-targeted mRNAs are altered in DCM. These microRNAs exhibit essential roles in regulating genes related to aforementioned various pathophysiologic pathways of DCM including hypertrophy, apoptosis, and fibrosis. MicroRNA-9, 21, 29, 30d, 34a, 144, 150, 320 and 378 correlated strongly to DCM and could be used as potential serum biomarkers in patients with DCM [109]. Although it is not clear whether exercise can normalize certain microRNAs expression in the myocardium, it is exciting to consider that exercise might be able to restore the expression of some microRNAs through cross-talk effect. For example, T2DM mice that participants in a 10-week swimming exercise regime exhibited increase the expression of microRNA-133 in cardiac tissue, improved contractile function, and decreased extracellular matrix regulator protein metallopeptidase-9 [110]. Since microRNA-133 is reportedly expressed and enriched in both cardiac and skeletal muscles [111]. Therefore, it is possible that after exercise skeletal muscles may secrete specific microRNAs into the circulation, which then travel to the cardiomyocytes to suppress fibrotic markers and reduce cardiac hypertrophy. The noticeable alterations in the microRNA profiles detected in myocardium and the circulation mirrors the underlying molecular pathology of DCM, which suggests that microRNAs may be effective biomarkers.

\section{Clinical perspective on the future use of exercise in DCM prevention}

Although recent research has advanced our understanding of the protective effects of exercise on the pathophysiology of DCM, there are no specific guidelines regarding the inclusion of exercise as a preventive or therapeutic modality for DCM clinical management. Even though the diastolic cardiac dysfunction is considered as the key step in DCM development [112,113], patients in the early stages of DCM generally do not present any clinical symptoms or signs $[114,115]$. Therefore, the majority of DCM patients remain asymptomatic until the later stages which are accompanied by systolic failure, at which point treatment modalities, including exercise, are ineffective. Since physical activity is restricted in the later stages of DCM [10], early diagnosis and proper preventive measures, including exercise, are crucial for both prevention and better prognosis of DCM.

It has been proposed that exercise during chemotherapy mitigates the doxorubicin-induced cardiomyopathy by restoring mitochondrial quality and redox signaling pathways [83]. Results from animal models have proven the effectiveness of exercisein preventing acute toxicity from a single dose of doxorubicin treatment $[55,57]$. Similar studies have shown that long-term exercisecould be an effective adjuvant treatment strategy against doxorubicin-related cardiac toxicity [56,84]. Recently, despite the limitations of a clinical human trial, the American Heart Association has suggested that personalized exercise therapy could be considered as a part of precision medicine for cancer patients to improve cardiovascular mortality $[116,117]$. Based on these recommendations, exercise may be presumed to influence an improved outcome in patients with DCM. If biomarkers or non-invasive imaging modalities could be used for early identification of high-risk patients $[48,118]$, it would be feasible to prescribe personalized exercise program based on risk stratification. Since exercise may not only mitigate cardiac dysfunction but also improve the outcome of T2DM [32,112,119-121], a therapeutic approach with a tailored exercise prescription would positively impact DCM management in the future. To this end, the development of tools for early diagnosis and optimization 
of risk stratification models would be pivotal, and in conjunction with well-designed clinical trials could provide the evidence to facilitate timely implementation.

\section{Conclusion}

Exercise is essential to maintain overall human health. Regular exercise is useful in the management of T2DM by mitigating the risk factors of associated comorbidities, including cardiovascular disease [32,39,121]. More importantly, exercise is a non-pharmacological intervention that can improve the outcome in patients with DCM by regulating cardiac mitochondrial metabolism, alleviating oxidative stress damage, and improving myocardial fibrosis, apoptosis, and vascular disorders $[10,11]$. Collectively, these possibilities suggest that exercise may have a potential role for inclusion in combination treatment for the prevention and treatment of DCM. However, future studies are warranted to provide molecular and clinical evidence before exercise can be included in the clinical management of DCM.

Author Contributions: D.Y.S., J.H.B., and J.H. contributed to the writing and editing of the manuscript; J.R.K., J.E.J., T.N.K., J.B.Y., and H.B.K. structured and revised the manuscript; A.H.K., K.S.K., B.D.R., and J.H. supervised, structured and contributed to editing the manuscript.

Funding: This work was supported by the Ministry of Education of the Republic of Korea and the National Research Foundation (NRF) of Korea (NRF-2010-0020224 and NRF-2018S1A5A8027802), by Basic Science Research Program through the National Research Foundation of Korea funded by the Ministry of Education (NRF2015R1D1A1A01056864 and NRF-2018R1D1A1B07040370), and the National Research Foundation of Korea grant funded by the Korean government (Ministry of Science and ICT, 2018R1A2A3074998).

Conflicts of Interest: The authors declare no conflict of interest.

\section{References}

1. Schmidt, A.M. Diabetes mellitus and cardiovascular disease. Arterioscler. Thromb. Vasc. Biol. 2019, 39, 558-568.

2. Rawshani, A.; Rawshani, A.; Franzen, S.; Sattar, N.; Eliasson, B.; Svensson, A.M.; Zethelius, B.; Miftaraj, M.; McGuire, D.K.; Rosengren, A., et al. Risk factors, mortality, and cardiovascular outcomes in patients with type 2 diabetes. N. Engl. J. Med. 2018, 379, 633-644.

3. Charnogursky, G.A.; Emanuele, N.V.; Emanuele, M.A. Neurologic complications of diabetes. Curr. Neurol. Neurosci. Rep. 2014, 14, 457.

4. Booth, G.L.; Kapral, M.K.; Fung, K.; Tu, J.V. Relation between age and cardiovascular disease in men and women with diabetes compared with non-diabetic people: a population-based retrospective cohort study. Lancet 2006, 368, 29-36.

5. Srivastava, P.; Badhwar, S.; Chandran, D.S.; Jaryal, A.K.; Jyotsna, V.P.; Deepak, K.K. Imbalance between Angiotensin II - angiotensin (1-7) system is associated with vascular endothelial dysfunction and inflammation in type 2 diabetes with newly diagnosed hypertension. Diabetes Metab. Syndr. 2019, 13, 2061-2068.

6. Althunibat, O.Y.; Al Hroob, A.M.; Abukhalil, M.H.; Germoush, M.O.; Bin-Jumah, M.; Mahmoud, A.M. Fisetin ameliorates oxidative stress, inflammation and apoptosis in diabetic cardiomyopathy. Life Sci. 2019, 221, 83-92.

7. Bai, S.Z.; Sun, J.; Wu, H.; Zhang, N.; Li, H.X.; Li, G.W.; Li, H.Z.; He, W.; Zhang, W.H.; Zhao, Y.J., et al. Decrease in calcium-sensing receptor in the progress of diabetic cardiomyopathy. Diabetes Res. Clin. Pract. 2012, 95, 378-385.

8. Malek, V.; Gaikwad, A.B. Telmisartan and thiorphan combination treatment attenuates fibrosis and apoptosis in preventing diabetic cardiomyopathy. Cardiovasc. Res. 2019, 115, 373-384. 
9. Chengji, W.; Xianjin, F. Exercise protects against diabetic cardiomyopathy by the inhibition of the endoplasmic reticulum stress pathway in rats. J. Cell Physiol. 2019, 234, 1682-1688.

10. Wang, H.; Bei, Y.; Lu, Y.; Sun, W.; Liu, Q.; Wang, Y.; Cao, Y.; Chen, P.; Xiao, J.; Kong, X. Exercise prevents cardiac injury and improves mitochondrial biogenesis in advanced diabetic cardiomyopathy with PGC-1alpha and Akt activation. Cell Physiol, Biochem, 2015, 35, 2159-2168.

11. Zheng, J.; Cheng, J.; Zheng, S.; Zhang, L.; Guo, X.; Zhang, J.; Xiao, X. Physical exercise and its protective effects on diabetic cardiomyopathy: what is the evidence? Front. Endocrinol. (Lausanne) 2018, 9, 729.

12. Moe, B.; Eilertsen, E.; Nilsen, T.I. The combined effect of leisure-time physical activity and diabetes on cardiovascular mortality: the nord-trondelag health (HUNT) cohort study, Norway. Diabetes Care. 2013, $36,690-695$.

13. Rubler, S.; Dlugash, J.; Yuceoglu, Y.Z.; Kumral, T.; Branwood, A.W.; Grishman, A. New type of cardiomyopathy associated with diabetic glomerulosclerosis. Am. J. Cardiol. 1972, 30, 595-602.

14. Adeghate, E.; Singh, J. Structural changes in the myocardium during diabetes-induced cardiomyopathy. Heart Fail. Rev. 2014, 19, 15-23.

15. Sakakibara, M.; Hirashiki, A.; Cheng, X.W.; Bando, Y.; Ohshima, K.; Okumura, T.; Funahashi, H.; Ohshima, S.; Murohara, T. Association of diabetes mellitus with myocardial collagen accumulation and relaxation impairment in patients with dilated cardiomyopathy. Diabetes Res. Clin. Pract. 2011, 92, 348355.

16. Paolillo, S.; Marsico, F.; Prastaro, M.; Renga, F.; Esposito, L.; De Martino, F.; Di Napoli, P.; Esposito, I.; Ambrosio, A.; Ianniruberto, M., et al. Diabetic cardiomyopathy: definition, diagnosis, and therapeutic implications. Heart Fail. Clin. 2019, 15, 341-347.

17. Evangelista, I.; Nuti, R.; Picchioni, T.; Dotta, F.; Palazzuoli, A. Molecular dysfunction and phenotypic derangement in diabetic cardiomyopathy. Int. J. Mol. Sci. 2019, 20(13), pii: E3264.

18. Seferovic, P.M.; Paulus, W.J. Clinical diabetic cardiomyopathy: a two-faced disease with restrictive and dilated phenotypes. Eur. Heart J. 2015, 36, 1718-1727.

19. Matthew Meng Yang Lee, J.J.V.M., Ana Lorenzo-Almorós, Søren Lund Kristensen, Naveed Sattar, Pardeep S Jhund, Mark C Petrie. Diabetic cardiomyopathy. Heart 2019, 105, 337-345.

20. Pan, Y.; Wang, Y.; Zhao, Y.; Peng, K.; Li, W.; Wang, Y.; Zhang, J.; Zhou, S.; Liu, Q.; Li, X., et al. Inhibition of JNK phosphorylation by a novel curcumin analog prevents high glucose-induced inflammation and apoptosis in cardiomyocytes and the development of diabetic cardiomyopathy. Diabetes 2014, 63, 34973511.

21. Mathis, D.R.; Liu, S.S.; Rodrigues, B.B.; McNeill, J.H. Effect of hypertension on the development of diabetic cardiomyopathy. Can. J. Physiol. Pharmacol. 2000, 78, 791-798.

22. Bell, D.S. Diabetic cardiomyopathy. A unique entity or a complication of coronary artery disease? Diabetes Care 1995, 18, 708-714.

23. Jonas, M.; Reicher-Reiss, H.; Boyko, V.; Shotan, A.; Mandelzweig, L.; Goldbourt, U.; Behar, S. Usefulness of beta-blocker therapy in patients with non-insulin-dependent diabetes mellitus and coronary artery disease. Bezafibrate Infarction Prevention (BIP) Study Group. Am. J. Cardiol. 1996, 77, 1273-1277.

24. Giacchetti, G.; Sechi, L.A.; Rilli, S.; Carey, R.M. The renin-angiotensin-aldosterone system, glucose metabolism and diabetes. Trends Endocrinol. Metab. 2005, 16, 120-126.

25. Yang, F.; Qin, Y.; Wang, Y.; Meng, S.; Xian, H.; Che, H.; Lv, J.; Li, Y.; Yu, Y.; Bai, Y., et al. Metformin Inhibits the NLRP3 Inflammasome via AMPK/mTOR-dependent effects in diabetic cardiomyopathy. Int. J. Biol. Sci. 2019, 15, 1010-1019. 
26. Takasu, T.; Takakura, S. Effect of ipragliflozin, an SGLT2 inhibitor, on cardiac histopathological changes in a non-diabetic rat model of cardiomyopathy. Life Sci. 2019, 230, 19-27.

27. Le Douairon Lahaye, S.; Bekono, F.R.; Broderick, T. Physical activity and diabetic cardiomyopathy: myocardial adaptation depending on exercise load. Curr. Diabetes Rev. 2014, 10, 371-390.

28. Vered, A.; Battler, A.; Segal, P.; Liberman, D.; Yerushalmi, Y.; Berezin, M.; Neufeld, H.N. Exerciseinduced left ventricular dysfunction in young men with asymptomatic diabetes mellitus (diabetic cardiomyopathy). Am. J. Cardiol. 1984, 54, 633-637.

29. Broderick, T.L.; Poirier, P.; Gillis, M. Exercise training restores abnormal myocardial glucose utilization and cardiac function in diabetes. Diabetes Metab. Res. Rev. 2005, 21, 44-50.

30. Mitka, M. Study: Exercise may match medication in reducing mortality associated with cardiovascular disease, diabetes. JAMA 2013, 310, 2026-2027.

31. McGavock, J.M.; Eves, N.D.; Mandic, S.; Glenn, N.M.; Quinney, H.A.; Haykowsky, M.J. The role of exercise in the treatment of cardiovascular disease associated with type 2 diabetes mellitus. Sports Med. 2004, 34, 27-48.

32. Hansen, D.; Dendale, P.; van Loon, L.J.; Meeusen, R. The impact of training modalities on the clinical benefits of exercise intervention in patients with cardiovascular disease risk or type 2 diabetes mellitus. Sports Med. 2010, 40, 921-940.

33. Taylor, J.D.; Fletcher, J.P.; Mathis, R.A.; Cade, W.T. Effects of moderate- versus high-intensity exercise training on physical fitness and physical function in people with type 2 diabetes: a randomized clinical trial. Phys. Ther. 2014, 94, 1720-1730.

34. Hansen, D.; Dendale, P.; Jonkers, R.A.; Beelen, M.; Manders, R.J.; Corluy, L.; Mullens, A.; Berger, J.; Meeusen, R.; van Loon, L.J. Continuous low- to moderate-intensity exercise training is as effective as moderate- to high-intensity exercise training at lowering blood $\mathrm{HbA}(1 \mathrm{c})$ in obese type 2 diabetes patients. Diabetologia 2009, 52, 1789-1797.

35. da Silva, D.E.; Grande, A.J.; Roever, L.; Tse, G.; Liu, T.; Biondi-Zoccai, G.; de Farias, J.M. High-intensity interval training in patients with type 2 diabetes mellitus: a systematic review. Curr. Atheroscler. Rep. $2019,21,8$.

36. Hu, G.; Jousilahti, P.; Barengo, N.C.; Qiao, Q.; Lakka, T.A.; Tuomilehto, J. Physical activity, cardiovascular risk factors, and mortality among Finnish adults with diabetes. Diabetes Care. 2005, 28, 799-805.

37. Karjalainen, J.; Peltonen, M.; Vanhala, M.; Korpi-Hyovalti, E.; Puolijoki, H.; Saltevo, J.; Oksa, H.; Saaristo, T.; Tuomilehto, J.; Kujala, U.M. Leisure time physical activity in individuals with screendetected type 2 diabetes compared to those with known type 2 diabetes. Diabetes Res. Clin. Pract. 2008, 81, 110-116.

38. Shinji, S.; Shigeru, M.; Ryusei, U.; Mitsuru, M.; Shigehiro, K. Adherence to a home-based exercise program and incidence of cardiovascular disease in type 2 diabetes patients. Int. J. Sports Med. 2007, 28, 877-879.

39. Scheede-Bergdahl, C.; Benee Olsen, D.; Reving, D.; Boushel, R.; Dela, F. Cardiovascular disease markers in type 2 diabetes: the effects of a moderate home-based exercise training programme. Diab. Vasc. Dis. Res. 2009, 6, 291-296.

40. American Diabetes, A. Standards of medical care in diabetes. Diabetes Care 2019, 42, S29-S30.

41. Garvey, W.T.; Hardin, D.; Juhaszova, M.; Dominguez, J.H. Effects of diabetes on myocardial glucose transport system in rats: implications for diabetic cardiomyopathy. Am. J. Physiol. 1993, 264, H837-844. 
42. Zamora, M.; Villena, J.A. Contribution of impaired insulin signaling to the pathogenesis of diabetic cardiomyopathy. Int. J. Mol. Sci. 2019, 20, (11), pii: E2833.

43. Huang, X.; Wu, D.; Cheng, Y.; Zhang, X.; Liu, T.; Liu, Q.; Xia, P.; Zhang, G.; Hu, S.; Liu, S. Restoration of myocardial glucose uptake with facilitated myocardial glucose transporter 4 translocation contributes to alleviation of diabetic cardiomyopathy in rats after duodenal-jejunal bypass. J. Diabetes Investig. 2019, 10, 626-638.

44. Rohling, M.; Herder, C.; Stemper, T.; Mussig, K. Influence of acute and chronic exercise on glucose uptake. J. Diabetes Res. 2016, 2016, 2868652.

45. Pedersen, B.K. Anti-inflammatory effects of exercise: role in diabetes and cardiovascular disease. Eur. J. Clin. Invest. 2017, 47, 600-611.

46. Parim, B.; Sathibabu Uddandrao, V.V.; Saravanan, G. Diabetic cardiomyopathy: molecular mechanisms, detrimental effects of conventional treatment, and beneficial effects of natural therapy. Heart Fail. Rev. 2019, 24, 279-299.

47. Loganathan, R.; Novikova, L.; Boulatnikov, I.G.; Smirnova, I.V. Exercise-induced cardiac performance in autoimmune (type 1) diabetes is associated with a decrease in myocardial diacylglycerol. J. Appl. Physiol. (1985) 2012, 113, 817-826.

48. Jonker, J.T.; de Mol, P.; de Vries, S.T.; Widya, R.L.; Hammer, S.; van Schinkel, L.D.; van der Meer, R.W.; Gans, R.O.; Webb, A.G.; Kan, H.E., et al. Exercise and type 2 diabetes mellitus: changes in tissue-specific fat distribution and cardiac function. Radiology 2013, 269, 434-442.

49. Cassidy, S.; Thoma, C.; Hallsworth, K.; Parikh, J.; Hollingsworth, K.G.; Taylor, R.; Jakovljevic, D.G.; Trenell, M.I. High intensity intermittent exercise improves cardiac structure and function and reduces liver fat in patients with type 2 diabetes: a randomised controlled trial. Diabetologia 2016, 59, 56-66.

50. Veeranki, S.; Givvimani, S.; Kundu, S.; Metreveli, N.; Pushpakumar, S.; Tyagi, S.C. Moderate intensity exercise prevents diabetic cardiomyopathy associated contractile dysfunction through restoration of mitochondrial function and connexin 43 levels in db/db mice. J. Mol. Cell. Cardiol. 2016, 92, 163-173.

51. Shao, C.H.; Wehrens, X.H.; Wyatt, T.A.; Parbhu, S.; Rozanski, G.J.; Patel, K.P.; Bidasee, K.R. Exercise training during diabetes attenuates cardiac ryanodine receptor dysregulation. J. Appl. Physiol. (1985) 2009, 106, 1280-1292.

52. Searls, Y.M.; Smirnova, I.V.; Fegley, B.R.; Stehno-Bittel, L. Exercise attenuates diabetes-induced ultrastructural changes in rat cardiac tissue. Med. Sci. Sports Exerc. 2004, 36, 1863-1870.

53. Quinteiro, H.; Buzin, M.; Conti, F.F.; Dias Dda, S.; Figueroa, D.; Llesuy, S.; Irigoyen, M.C.; Sanches, I.C.; De Angelis, K. Aerobic exercise training promotes additional cardiac benefits better than resistance exercise training in postmenopausal rats with diabetes. Menopause 2015, 22, 534-541.

54. Novoa, U.; Arauna, D.; Moran, M.; Nunez, M.; Zagmutt, S.; Saldivia, S.; Valdes, C.; Villasenor, J.; Zambrano, C.G.; Gonzalez, D.R. High-intensity exercise reduces cardiac fibrosis and hypertrophy but does not restore the nitroso-redox imbalance in diabetic cardiomyopathy. Oxid. Med. Cell Longev. 2017, $2017,7921363$.

55. Kavazis, A.N.; Smuder, A.J.; Min, K.; Tumer, N.; Powers, S.K. Short-term exercise training protects against doxorubicin-induced cardiac mitochondrial damage independent of HSP72. Am. J. Physiol. Heart Circ. Physiol. 2010, 299, H1515-1524.

56. Dolinsky, V.W.; Rogan, K.J.; Sung, M.M.; Zordoky, B.N.; Haykowsky, M.J.; Young, M.E.; Jones, L.W.; Dyck, J.R. Both aerobic exercise and resveratrol supplementation attenuate doxorubicin-induced cardiac injury in mice. Am. J. Physiol. Endocrinol. Metab. 2013, 305, E243-253. 
57. Ascensao, A.; Magalhaes, J.; Soares, J.M.; Ferreira, R.; Neuparth, M.J.; Marques, F.; Oliveira, P.J.; Duarte, J.A. Moderate endurance training prevents doxorubicin-induced in vivo mitochondriopathy and reduces the development of cardiac apoptosis. Am. J. Physiol. Heart Circ. Physiol. 2005, 289, H722-731.

58. Suarez, J.; Scott, B.; Dillmann, W.H. Conditional increase in SERCA2a protein is able to reverse contractile dysfunction and abnormal calcium flux in established diabetic cardiomyopathy. Am. J. Physiol. Regul. Integr. Comp. Physiol. 2008, 295, R1439-1445.

59. Ziegelhoffer, A.; Ravingerova, T.; Styk, J.; Tribulova, N.; Volkovova, K.; Sebokova, J.; Breier, A. Diabetic cardiomyopathy in rats: biochemical mechanisms of increased tolerance to calcium overload. Diabetes Res. Clin. Pract. 1996, 31 Suppl, S93-103.

60. Mozaffari, M.S.; Allo, S.; Schaffer, S.W. The effect of sulfonylurea therapy on defective calcium movement associated with diabetic cardiomyopathy. Can. J. Physiol. Pharmacol. 1989, 67, 1431-1436.

61. Lira, V.A.; Benton, C.R.; Yan, Z.; Bonen, A. PGC-1alpha regulation by exercise training and its influences on muscle function and insulin sensitivity. Am. J. Physiol. Endocrinol. Metab. 2010, 299, E145E161.

62. Nikolaidis, L.A.; Levine, T.B. Peroxisome proliferator activator receptors (PPAR), insulin resistance, and cardiomyopathy: friends or foes for the diabetic patient with heart failure? Cardiol. Rev. 2004, 12, 158-170.

63. Hafstad, A.D.; Boardman, N.; Aasum, E. How exercise may amend metabolic disturbances in diabetic cardiomyopathy. Antioxid. Redox. Signal. 2015, 22, 1587-1605.

64. Mahmoud, A.M. Exercise amaliorates metabolic disturbances and oxidative stress in diabetic cardiomyopathy: possible underlying mechanisms. Adv. Exp. Med. Biol. 2017, 999, 207-230.

65. Joubert, M.; Manrique, A.; Cariou, B.; Prieur, X. Diabetes-related cardiomyopathy: The sweet story of glucose overload from epidemiology to cellular pathways. Diabetes Metab. 2019, 45, 238-247.

66. Berthiaume, J.M.; Kurdys, J.G.; Muntean, D.M.; Rosca, M.G. Mitochondrial NAD(+)/NADH redox state and diabetic cardiomyopathy. Antioxid. Redox Signal. 2019, 30, 375-398.

67. Wu, H.; Liu, G.; He, Y.; Da, J.; Xie, B. Obeticholic acid protects against diabetic cardiomyopathy by activation of FXR/Nrf2 signaling in db/db mice. Eur. J. Pharmacol. 2019, 858, 172393.

68. Li, L.; Luo, W.; Qian, Y.; Zhu, W.; Qian, J.; Li, J.; Jin, Y.; Xu, X.; Liang, G. Luteolin protects against diabetic cardiomyopathy by inhibiting NF-kappaB-mediated inflammation and activating the Nrf2mediated antioxidant responses. Phytomedicine 2019, 59, 152774.

69. He, X.; Ma, Q. Disruption of Nrf2 synergizes with high glucose to cause heightened myocardial oxidative stress and severe cardiomyopathy in diabetic mice. J. Diabetes Metab. 2012, Suppl 7.

70. Guan, Y.; Zhou, L.; Zhang, Y.; Tian, H.; Li, A.; Han, X. Effects of PP2A/Nrf2 on experimental diabetes mellitus-related cardiomyopathy by regulation of autophagy and apoptosis through ROS dependent pathway. Cell Signal. 2019, 62, 109339.

71. Ge, Z.D.; Lian, Q.; Mao, X.; Xia, Z. Current status and challenges of NRF2 as a potential therapeutic target for diabetic cardiomyopathy. Int. Heart J. 2019, 60, 512-520.

72. Zhu, Z.D.; Ye, J.M.; Fu, X.M.; Wang, X.C.; Ye, J.Y.; Wu, X.R.; Hua, P.; Liao, Y.Q.; Xuan, W.; Duan, J.L., et al. DDAH2 alleviates myocardial fibrosis in diabetic cardiomyopathy through activation of the DDAH/ADMA/NOS/NO pathway in rats. Int. J. Mol. Med. 2019, 43, 749-760.

73. Zhao, T.; Chen, H.; Xu, F.; Wang, J.; Liu, Y.; Xing, X.; Guo, L.; Zhang, M.; Lu, Q. Liraglutide alleviates cardiac fibrosis through inhibiting P4halpha-1 expression in STZ-induced diabetic cardiomyopathy. Acta. Biochim. Biophys. Sin. (Shanghai) 2019, 51, 293-300. 
74. Meng, S.; Yang, F.; Wang, Y.; Qin, Y.; Xian, H.; Che, H.; Wang, L. Silymarin ameliorates diabetic cardiomyopathy via inhibiting TGF-beta1/Smad signaling. Cell Biol. Int. 2019, 43, 65-72.

75. Liu, X.; Xu, Q.; Wang, X.; Zhao, Z.; Zhang, L.; Zhong, L.; Li, L.; Kang, W.; Zhang, Y.; Ge, Z. Irbesartan ameliorates diabetic cardiomyopathy by regulating protein kinase $\mathrm{D}$ and ER stress activation in a type 2 diabetes rat model. Pharmacol. Res. 2015, 93, 43-51.

76. Li, K.; Zhai, M.; Jiang, L.; Song, F.; Zhang, B.; Li, J.; Li, H.; Li, B.; Xia, L.; Xu, L., et al. Tetrahydrocurcumin ameliorates diabetic cardiomyopathy by attenuating high glucose-induced oxidative stress and fibrosis via activating the SIRT1 pathway. Oxid. Med. Cell Longev. 2019, 2019, 6746907.

77. Giugliano, D.; Maiorino, M.I.; Bellastella, G.; Chiodini, P.; Esposito, K. Glycemic control, preexisting cardiovascular disease, and risk of major cardiovascular events in patients with type 2 diabetes mellitus: systematic review with meta-analysis of cardiovascular outcome trials and intensive glucose control trials. J. Am. Heart. Assoc. 2019, 8, e012356.

78. Kang, Y.; Wang, S.; Huang, J.; Cai, L.; Keller, B.B. Right ventricular dysfunction and remodeling in diabetic cardiomyopathy. Am. J. Physiol. Heart. Circ. Physiol. 2019, 316, H113-H122.

79. Zuo, G.; Ren, X.; Qian, X.; Ye, P.; Luo, J.; Gao, X.; Zhang, J.; Chen, S. Inhibition of JNK and p38 MAPKmediated inflammation and apoptosis by ivabradine improves cardiac function in streptozotocininduced diabetic cardiomyopathy. J. Cell Physiol. 2019, 234, 1925-1936.

80. Yu, Y.; Zheng, G. Troxerutin protects against diabetic cardiomyopathy through NFkappaB/AKT/IRS1 in a rat model of type 2 diabetes. Mol. Med. Rep. 2017, 15, 3473-3478.

81. Muscogiuri, G.; Chavez, A.O.; Gastaldelli, A.; Perego, L.; Tripathy, D.; Saad, M.J.; Velloso, L.; Folli, F. The crosstalk between insulin and renin-angiotensin-aldosterone signaling systems and its effect on glucose metabolism and diabetes prevention. Curr. Vasc. Pharmacol. 2008, 6, 301-312.

82. Li, S.; Liu, R.; Xue, M.; Qiao, Y.; Chen, Y.; Long, G.; Tian, X.; Hu, Y.; Zhou, P.; Dong, X., et al. Spleen tyrosine kinaseinduced JNKdependent NLRP3 activation is involved in diabetic cardiomyopathy. Int. J. Mol. Med. 2019, 43, 2481-2490.

83. Marques-Aleixo, I.; Santos-Alves, E.; Oliveira, P.J.; Moreira, P.I.; Magalhaes, J.; Ascensao, A. The beneficial role of exercise in mitigating doxorubicin-induced Mitochondrionopathy. Biochim. Biophys. Acta. Rev. Cancer 2018, 1869, 189-199.

84. Kanter, M.M.; Hamlin, R.L.; Unverferth, D.V.; Davis, H.W.; Merola, A.J. Effect of exercise training on antioxidant enzymes and cardiotoxicity of doxorubicin. J. Appl. Physiol. (1985) 1985, 59, 1298-1303.

85. Luo, W.; Jin, Y.; Wu, G.; Zhu, W.; Qian, Y.; Zhang, Y.; Li, J.; Zhu, A.; Liang, G. Blockage of ROS and MAPKs-mediated inflammation via restoring SIRT1 by a new compound LF10 prevents type 1 diabetic cardiomyopathy. Toxicol. Appl. Pharmacol. 2019, 370, 24-35.

86. Knapp, M.; Tu, X.; Wu, R. Vascular endothelial dysfunction, a major mediator in diabetic cardiomyopathy. Acta. Pharmacol. Sin. 2019, 40, 1-8.

87. Okada, S.; Hiuge, A.; Makino, H.; Nagumo, A.; Takaki, H.; Konishi, H.; Goto, Y.; Yoshimasa, Y.; Miyamoto, Y. Effect of exercise intervention on endothelial function and incidence of cardiovascular disease in patients with type 2 diabetes. J. Atheroscler. Thromb. 2010, 17, 828-833.

88. Stewart, K.J. Role of exercise training on cardiovascular disease in persons who have type 2 diabetes and hypertension. Cardiol. Clin. 2004, 22, 569-586.

89. Lorenzo-Almoros, A.; Tunon, J.; Orejas, M.; Cortes, M.; Egido, J.; Lorenzo, O. Diagnostic approaches for diabetic cardiomyopathy. Cardiovasc. Diabetol. 2017, 16, 28. 
90. Pennica, D.; King, K.L.; Shaw, K.J.; Luis, E.; Rullamas, J.; Luoh, S.M.; Darbonne, W.C.; Knutzon, D.S.; Yen, R.; Chien, K.R., et al. Expression cloning of cardiotrophin 1, a cytokine that induces cardiac myocyte hypertrophy. Proc. Natl. Acad. Sci. U S A 1995, 92, 1142-1146.

91. Ruiz-Hurtado, G.; Gomez-Hurtado, N.; Fernandez-Velasco, M.; Calderon, E.; Smani, T.; Ordonez, A.; Cachofeiro, V.; Bosca, L.; Diez, J.; Gomez, A.M., et al. Cardiotrophin-1 induces sarcoplasmic reticulum $\mathrm{Ca}(2+)$ leak and arrhythmogenesis in adult rat ventricular myocytes. Cardiovasc. Res. 2012, 96, 81-89.

92. Jougasaki, M. Cardiotrophin-1 in cardiovascular regulation. Adv. Clin. Chem. 2010, 52, 41-76.

93. Limongelli, G.; Calabro, P.; Maddaloni, V.; Russo, A.; Masarone, D.; D'Aponte, A.; Roselli, T.; Bonauro, R.; D'Alessandro, R.; D'Andrea, A., et al. Cardiotrophin-1 and TNF-alpha circulating levels at rest and during cardiopulmonary exercise test in athletes and healthy individuals. Cytokine 2010, 50, 245-247.

94. Nyman, K.; Graner, M.; Pentikainen, M.O.; Lundbom, J.; Hakkarainen, A.; Siren, R.; Nieminen, M.S.; Taskinen, M.R.; Lundbom, N.; Lauerma, K. Cardiac steatosis and left ventricular function in men with metabolic syndrome. J. Cardiovasc. Magn. Reson. 2013, 15, 103.

95. Chen, W.J.; Greulich, S.; van der Meer, R.W.; Rijzewijk, L.J.; Lamb, H.J.; de Roos, A.; Smit, J.W.; Romijn, J.A.; Ruige, J.B.; Lammertsma, A.A., et al. Activin A is associated with impaired myocardial glucose metabolism and left ventricular remodeling in patients with uncomplicated type 2 diabetes. Cardiovasc. Diabetol. 2013, 12, 150 .

96. Perakakis, N.; Mougios, V.; Fatouros, I.; Siopi, A.; Draganidis, D.; Peradze, N.; Ghaly, W.; Mantzoros, C.S. Physiology of activins/follistatins: associations with metabolic and anthropometric variables and response to exercise. J. Clin. Endocrinol. Metab. 2018, 103, 3890-3899.

97. Carley, A.N.; Severson, D.L. Fatty acid metabolism is enhanced in type 2 diabetic hearts. Biochim. Biophys. Acta. 2005, 1734, 112-126.

98. Hoffmann, U.; Espeter, F.; Weiss, C.; Ahmad-Nejad, P.; Lang, S.; Brueckmann, M.; Akin, I.; Neumaier, M.; Borggrefe, M.; Behnes, M. Ischemic biomarker heart-type fatty acid binding protein (hFABP) in acute heart failure - diagnostic and prognostic insights compared to NT-proBNP and troponin I. BMC Cardiovasc. Disord. 2015, 15, 50.

99. Akbal, E.; Ozbek, M.; Gunes, F.; Akyurek, O.; Ureten, K.; Delibasi, T. Serum heart type fatty acid binding protein levels in metabolic syndrome. Endocrine 2009, 36, 433-437.

100. Chen, C.Y.; Hsu, H.C.; Lee, B.C.; Lin, H.J.; Chen, Y.H.; Huang, H.C.; Ho, Y.L.; Chen, M.F. Exercise training improves cardiac function in infarcted rabbits: involvement of autophagic function and fatty acid utilization. Eur. J. Heart Fail. 2010, 12, 323-330.

101. Jones, J.D.; Chew, P.G.; Dobson, R.; Wootton, A.; Ashrafi, R.; Khand, A. The prognostic value of heart type fatty acid binding protein in patients with suspected acute coronary syndrome: a systematic review. Curr. Cardiol. Rev. 2017, 13, 189-198.

102. Asbun, J.; Villarreal, F.J. The pathogenesis of myocardial fibrosis in the setting of diabetic cardiomyopathy. J. Am. Coll. Cardiol. 2006, 47, 693-700.

103. Ruan, W.; Lai, M. Insulin-like growth factor binding protein: a possible marker for the metabolic syndrome? Acta. Diabetol, 2010, 47, 5-14.

104. Gandhi, P.U.; Gaggin, H.K.; Sheftel, A.D.; Belcher, A.M.; Weiner, R.B.; Baggish, A.L.; Motiwala, S.R.; Liu, P.P.; Januzzi, J.L., Jr. Prognostic usefulness of insulin-like growth factor-binding protein 7 in heart failure with reduced ejection fraction: a novel biomarker of myocardial diastolic function? Am. J. Cardiol. 2014, 114, 1543-1549.

105. Guo, X.H.; Liu, L.X.; Zhang, H.Y.; Zhang, Q.Q.; Li, Y.; Tian, X.X.; Qiu, Z.H. Insulin-like growth factor binding protein-related protein 1 contributes to hepatic fibrogenesis. J. Dig. Dis. 2014, 15, 202-210. 
106. Shaver, A.; Nichols, A.; Thompson, E.; Mallick, A.; Payne, K.; Jones, C.; Manne, N.D.; Sundaram, S.; Shapiro, J.I.; Sodhi, K. Role of serum biomarkers in early detection of diabetic cardiomyopathy in the west virginian population. Int. J. Med. Sci. 2016, 13, 161-168.

107. Zhou, Q.; Lv, D.; Chen, P.; Xu, T.; Fu, S.; Li, J.; Bei, Y. MicroRNAs in diabetic cardiomyopathy and clinical perspectives. Front. Genet. 2014, 5, 185.

108. Shantikumar, S.; Caporali, A.; Emanueli, C. Role of microRNAs in diabetes and its cardiovascular complications. Cardiovasc. Re.s 2012, 93, 583-593.

109. Guo, R.; Nair, S. Role of microRNA in diabetic cardiomyopathy: From mechanism to intervention. Biochim. Biophys. Acta. Mol. Basis. Dis. 2017, 1863, 2070-2077.

110. Mishra, P.K.; Awe, O.; Metreveli, N.; Qipshidze, N.; Munjal, C.; Tyagi, N.; Tyagi, S.C. Exercise ameliorates diabetic cardiomyopathy by inducing beta2-adrenergic receptors and miR-133a, and attenuating MMP-9. Faseb J. 2011, 25.

111. Rawal, S.; Manning, P.; Katare, R. Cardiovascular microRNAs: as modulators and diagnostic biomarkers of diabetic heart disease. Cardiovascular. Diabetology 2014, 13, 44.

112. Regensteiner, J.G.; Bauer, T.A.; Reusch, J.E.; Quaife, R.A.; Chen, M.Y.; Smith, S.C.; Miller, T.M.; Groves, B.M.; Wolfel, E.E. Cardiac dysfunction during exercise in uncomplicated type 2 diabetes. Med. Sci. Sports Exerc. 2009, 41, 977-984.

113. Pinto, T.E.; Gusso, S.; Hofman, P.L.; Derraik, J.G.; Hornung, T.S.; Cutfield, W.S.; Baldi, J.C. Systolic and diastolic abnormalities reduce the cardiac response to exercise in adolescents with type 2 diabetes. Diabetes Care 2014, 37, 1439-1446.

114. Teupe, C.; Rosak, C. Diabetic cardiomyopathy and diastolic heart failure difficulties with relaxation. Diabetes Res. Clin. Pract. 2012, 97, 185-194.

115. Murtaza, G.; Virk, H.U.H.; Khalid, M.; Lavie, C.J.; Ventura, H.; Mukherjee, D.; Ramu, V.; Bhogal, S.; Kumar, G.; Shanmugasundaram, M., et al. Diabetic cardiomyopathy - A comprehensive updated review. Prog. Cardiovasc. Dis. 2019, Epub ahead of print.

116. Scott, J.M.; Nilsen, T.S.; Gupta, D.; Jones, L.W. Exercise therapy and cardiovascular toxicity in cancer. Circulation 2018, 137, 1176-1191.

117. Zhao, M.; Veeranki, S.P.; Li, S.; Steffen, L.M.; Xi, B. Beneficial associations of low and large doses of leisure time physical activity with all-cause, cardiovascular disease and cancer mortality: a national cohort study of 88,140 US adults. Br. J. Sports Med. 2019, Epub ahead of print.

118. Khanna, N.N.; Jamthikar, A.D.; Araki, T.; Gupta, D.; Piga, M.; Saba, L.; Carcassi, C.; Nicolaides, A.; Laird, J.R.; Suri, H.S., et al. Nonlinear model for the carotid artery disease 10-year risk prediction by fusing conventional cardiovascular factors to carotid ultrasound image phenotypes: A Japanese diabetes cohort study. Echocardiography 2019, 36, 345-361.

119. Verboven, M.; Van Ryckeghem, L.; Belkhouribchia, J.; Dendale, P.; Eijnde, B.O.; Hansen, D.; Bito, V. Effect of exercise intervention on cardiac function in type 2 diabetes mellitus: a systematic review. Sports Med. 2019, 49, 255-268.

120. Roberts, T.J.; Burns, A.T.; MacIsaac, R.J.; MacIsaac, A.I.; Prior, D.L.; La Gerche, A. Exercise capacity in diabetes mellitus is predicted by activity status and cardiac size rather than cardiac function: a case control study. Cardiovasc. Diabetol. 2018, 17, 44.

121. Bhati, P.; Shenoy, S.; Hussain, M.E. Exercise training and cardiac autonomic function in type 2 diabetes mellitus: A systematic review. Diabetes Metab. Syndr. 2018, 12, 69-78. 